\title{
Future Humanitarian Crises: Challenges for Practice, Policy, and Public Health
}

\author{
Frederick M. Burkle, Jr., MD, MPH, DTM
}

Senior Fellow \& Visiting Scientist, Harvard Humanitarian Initiative, Harvard University, Cambridge, Massachusetts USA; Senior Public Policy Scholar, Woodrow Wilson International Center for Scholars, Washington, DC USA; Section Editor for Humanitarian Affairs, Prehospital and Disaster Medicine

\section{Correspondence: \\ E-mail: fburkle@hsph.harvard.edu}

Keywords: disaster; future crisis; global health humanitarian crises; public health emergency

Prepared for the Spring, 2010 Global Health: Pandemics, Poverty and Policy Symposium, DePaul University College of Law, Health Law Institute, Chicago, Illinois USA.

Web publication: 03 June 2010

\begin{abstract}
After more than three decades of preoccupation with wars and internal political conflicts, the humanitarian community has the opportunity to re-evaluate what humanitarian crises will dominate both policy and practice in the future. In reality, these crises are already active and some are over the tipping point of recovery. These crises share the common thread of being major public health emergencies which, with a preponderance of excess or indirect mortality and morbidity dominating the consequences, requires new approaches, including unprecedented improvements and alterations in education, training, research, strategic planning, and policy and treaty agendas. Unfortunately, political solutions offered up to date are nation-state centric and miss opportunities to provide what must be global solutions. Public health, redefined as the infrastructure and systems necessary to allow communities, urban settings, and nation-states to provide physical and social protections to their populations has become an essential element of all disciplines from medicine, engineering, law, social sciences, and economics. Public health, which must be recognized as a strategic and security issue should take precedence over politics at every level, not be driven by political motives, and be globally monitored.
\end{abstract}

Burkle FM Jr: Future humanitarian crises: Challenges for practice, policy and public health. Prehosp Disaster Med 2010;25(3):191-198.

The Rise of Public Health Emergencies

Public health emergencies (PHE) are defined as crises that "adversely impact the public health system and its protective infrastructure that includes water, sanitation, shelter, food, and health." 1 An increasingly common thread of PHEs have permeated and often dominated the consequences brought on by wars, conflicts, and large-scale disasters in the last third of the 20th century. Public health emergencies occur when the public health protective threshold is destroyed as it is during war; overwhelmed, as it was for the citizens of New Orleans after Hurricane Katrina; not recovered or maintained, as it was when Shia' public health infrastructures south of Baghdad were destroyed by the first Persian Gulf War and purposely ignored by the Saddam regime causing the worst health indices in all of Iraq; or denied, as they were to select ethnic and religious groups during the Post-Cold War internal conflicts and persist for many in the decades long smoldering conflicts of Sudan, Haiti, and Palestine. ${ }^{2}$

In the developed world, public health protections are literally invisible to populations where they are taken for granted. The lack of public health protections is what distinguishes many of the 'have and have not populations' of the world. Wars and large-scale disasters, such as earthquakes and hurricanes, are defined by the direct deaths and injuries they produce. Yet, in a very short time, indirect or preventable deaths from the loss of and failure to recover the public health protections can rapidly eclipse the number of direct mortalities.

There has been little investment in public health infrastructures in all parts of the world. Traditionally, public health systems get the short-end of the stick in funding and human resources, especially in those departments concerned with disaster prevention and preparedness. Post $9 / 11$, Federal funding greatly improved the capacity of the 2,800 local and state health departments in the 
United States to investigate and control pandemics and the consequences of terrorist events. With recent fiscal constraints both State and Federal funding has declined, leaving many States with considerable gaps in their ability to respond to PHEs. A recent study completed by the Centers for Disease Control and Prevention found that epidemiological capacity, critical to outbreak surveillance and control, decreased between 2006 and 2009. ${ }^{3}$

Public health infrastructures and systems globally have declined, disappeared, or failed to keep pace with the demands of population growth and density. We have entered the 21 st century with deficient dwellings, aged and inadequate infrastructure, and insufficient capacity to respond to crises, especially in ensuring access to safe water, food, sanitation, and energy. Ecological and environmental preservations must be considered as essential public health protections. Haiti is an example where decade's long deforestation decimated the protective root structure to an alarming $1 \% .4,5$ When a hurricane hits Haiti, Cuba, and then Florida...the direct deaths are similar in number. However, in the absence of normal protective root structures from trees, the torrential rains led to massive flooding and mudslides in Haiti, resulting in an additional 2,500 or more indirect deaths. When a major disaster hits the island of Hispaniola, the impacts are decidedly worse for the deforested Haiti than the forested Dominican Republic.

Indirect mortality and morbidity is considered preventable. At first glance, all of the "future" humanitarian crises addressed in this paper may seem distinct, but they have in common, a propensity to result in major PHEs. In fact, it is a dominant characteristic in all. However, neither policy nor public health are prepared to address the root causes or the consequences of PHEs-especially at the local operational or community level.

\section{Future Crises}

For the last three decades, conventional cross-border, internal complex, and asymmetrical wars have dominated our will and diverted attention away from more subtle and slowly emerging crises - all of which have an even greater impact on public health. Governments always have been uncomfortable with public health data. Political parties in power own the public health leadership, budgets, and the agendas that are deemed important and those that are tabled. In the last two decades, there has been a deliberate efforts by governments to influence, control, and interpret public health data in a favorable light for political gains. The scientific community, often reticent to enter political disputes, has not been stellar in its capacity to interpret public health consequences in a manner easily understood by the citizenry or decision-makers.

\section{War and Conflict}

There is no reason to expect that wars, especially asymmetrical warring, will show a decline. The Democratic Republic of the Congo, Somalia, and the Occupied Palestinian Territories will remain chronic and smoldering. Nigeria has every reason to be the next Muslim/Christian hotspot. The Western world, at least the United States, will remain mired in many asymmetrical conflicts that have no easy solution, certainly no conventional one. The internal complex wars of the last three decades were post-Cold War battles over territory and resources. Asymmetrical wars, such as Iraq and Afghanistan, focus on controlling a population bringing all ethnic, religious, and tribal factions into the fray. Territory and resources are a side benefit that is not necessarily an immediate priority of insurgent movements. Asymmetrical warfare has three components that deserve equal attention: the asymmetrical warfare itself, the pervasive insecurity that impacts all elements of society, especially the civilians and aid community, and the emergence, over time, of an unprecedented, prolonged, and catastrophic PHE (Figure 1). ${ }^{6}$

During 2003 Iraq, the humanitarian community warned the coalition military of the danger of not recognizing the impact of asymmetrical war on civilians. This was several years before the "troop surge" became the soup de jure solution, in 2007 to protect and "win the hearts and minds" of the populace. In the interim, public health indices, including chronic malnutrition, infant mortality rates, and preventable mortality and morbidity all severely worsened, and which remain even today. Often lost among the attention given to direct violence, social, ethnic, religious disparities and inequities, poverty, injustices, cultural incompatibilities, ignorance, racism, oppression, and religious fundamentalism all will adversely impact the public health and prevent or slow its recovery. In an early 2010 report, nearly $80 \%$ of the already 300,000 conflict-related deaths in Darfur were due to preventable infectious diseases, not violence. ${ }^{7}$ In a 2001 Congo study, this figure was $90 \%{ }^{8}$

\section{Post-Conflict Nation-States}

History will show that a shameful chapter in humanitarian assistance is the failure of the international community to recover and rehabilitate post-conflict nation-states. The transition phase from war, before sustainable development is realized, is the most dangerous. Social and political scientists have shown that the number of victims of preventable mortality and morbidity predictably rise once the war has been declared over. These indirect mortalities usually represent 70 to $90 \%$ of all the deaths during the war itself, yet markedly increase after the "shooting has stopped." ${ }^{\prime \prime}$ Those indirect deaths remain high for years and do not reach the pre-war baseline for a decade or more. With a declaration of peace, tentative or not, the humanitarian community, including donors, withdraw as funding and media attention disappears. The developed world is quite receptive at responding to emergencies with finding donors and available humanitarian staff to "save lives." However, interest in the hard work of sustainable recovery and rehabilitation seems to be more risky, less receptive, and poorly understood. Indeed, decision-makers are less clear as to what needs to be done and by whom. What is agreed upon is that it takes unprecedented degrees of collaboration, coordination, and communication, a level that is not initially required during the war's humanitarian effort.

Whereas deaths from wars have declined, the number of people exposed to conflict has increased. ${ }^{10} \mathrm{~A}$ major mistake is to assume that once there is some semblance of a declaration of peace, violent conflict ceases. The term "post-conflict" is somewhat of a myth. It does not necessarily mean 


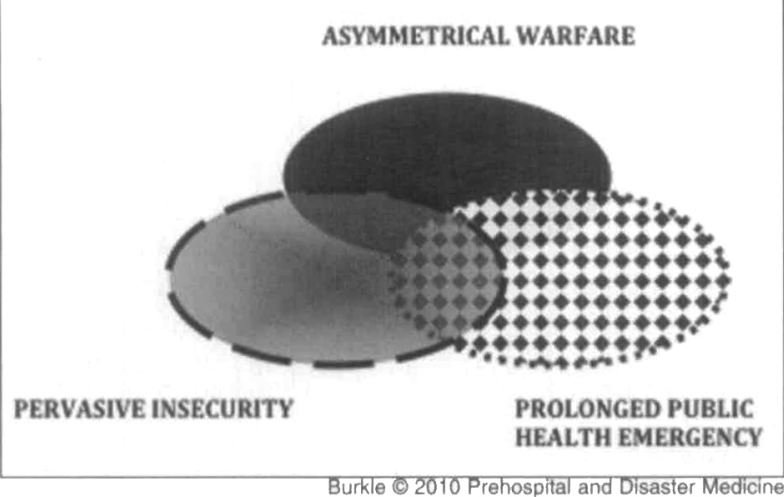

Figure 1-Three equally critical and integrated characteristics of asymmetrical warfare.

Reproduced from: Burkle FM Jr. Measuring humanitarian assistance in conflicts. Lancet 2008;19(371)(9608):189-190, with permission from Elsevier

there is peace. The difference between populations at war and during the post-conflict phase gets blurred with continued varying levels of conflict intensity. Many of the same violent events continue, but now are termed "criminality or banditry", thus speaking to both the urge to affirm that peace has finally arrived and a certain degree of collective denial. For example, security level decision-makers may categorize the post-conflict environment through their own 'language-lens' viewed simply as being 'permissive, nonpermissive, or semi-permissive'. Among the confounding variables that make current post-conflict environments different than the celebrated post-World War II recovery, is the massive proliferation and easy availability of weaponry, factors that intimidate the debate toward lasting peace and civility.

Unfortunately $47 \%$ of countries return to conflict within a decade, with a rate that is $60 \%$ in $A$ frica. ${ }^{11}$ It must be remembered that the post-conflict infrastructure and system is usually $10 \%$ of what it was before the war. Predictors of a return to war include stagnation of economic recovery and worsening of the infant mortality rate (IMR), a composite index which has less to do with the availability of prenatal, antenatal, and postnatal care than it has to do with combined capacities to organize such services through good governance. Additionally, if the mortality rate remains at the wartime emergency threshold level of 2.0 deaths $/ 10,000 /$ day and the fledgling government lacks the public health infrastructure and healthcare resources to adequately manage it-inevitably, warring will restart.

Post-conflict failures are tragic and increasingly add to the list of "fragile states". Successful progress requires a coordinated mix of military, government, health, education, economic, and other resources-all patiently working together from an agreed upon strategic plan. Humanitarian assistance should not cease, rather it may need to be escalated for the short term so that the population can witness an improvement of quality health care, education, and employment. The post-conflict players must recognize that the transition period remains dangerous for the most vulnerable populations of women, children, and those with mental health problems.

Despite an overall weak track record, successes helped by strategic planning do exist in East Timor, Liberia, Rwanda, and others. Despite the desperation, the complex post-conflict environment and the basic public health needs has captured little attention among governments, donors, and practitioners alike. The knowledge base is scant. Where epidemiological studies proliferated in the war and conflict literature, few studies of the post-conflict environment are available or funded; if it is not being measured, then it does not exist.

\section{Biodiversity Crises}

Biodiversity systems are areas throughout the world where the major life forms that sustain our global 'biology' are found. It is in these areas where the large majority of the crucial 1,500 vascular plant species, and at least $70 \%$ of original vertebrates, reside and define the foundation for sustaining the 'public health' of the planet. ${ }^{12}$ Biodiversity hotspots, of which there are 34 , are regions with a uniquely rich level of endemic species that also are most threatened. ${ }^{13}$ Understandably, dense human habitation tends to occur near biodiversity hotspots, most of which are large forests or located in the tropics.

Tragically, $80 \%$ of the major conflicts and wars of the last three decades occurred in 23 of the 34 most biologically diverse and threatened places. ${ }^{12}$ Iraq is just one example, where only $6 \%$ of land is arable, packed between and sustained by the Tigris and Euphrates rivers. The ongoing war, drought, and increasing dust storms have severely degraded the once fertile soil. Ambitious plans by Turkey and Syria to divert the rivers from their origins with dams and hydroelectric plants may prove to be the final blow to Iraq's agricultural economy. Iraq's Minister of the Environment, Narmin Othman, claimed in January 2010, that environmental degradation is being intensified by an acute drought and water shortage across the country that has seen a $70 \%$ decrease in the volume of water flowing through the two rivers as they enter the country from the north. Othman emphasized, "We can no longer in good conscience call ourselves the land between the rivers. A lot of the water we are getting has first been used by Turkey and Syria for power generation. When it reaches us, it is poor quality. That water which is used for agriculture is often contaminated. We are in the midst of an unmatched environmental disaster."14

Worldwide overpopulation, deforestation, pollution, and global warming have produced a negative cumulative effect on these sensitive ecosystems that some studies warn is destined for collapse. For the United States, the south-costal area of California is the only robust biodiversity system in America and a major contributor to its sustainable food supply. Other countries' biodiversity assets have endowed war funding, most notably in the Congo and Cambodia from timber harvesting and the over-production of illicit drug crops that have dominated and scavenged agricultural lands in Afghanistan, South East Asia, and Latin America. ${ }^{15}$ Even after the wars, the lingering level of fighting in many post-conflict environments has stymied the recovery of their once robust biodiversity systems. Additionally, the wide availability of weapons provides easy means to kill small animals for bush meat, severely depleting the remaining vertebrate populations. ${ }^{16}$

The resources focused in these unique biodiversity areas of the world must be recognized as "global resources," not a 
commodity that can be owned by any one nation-state. The nation-states in which they reside are their protectorates and have a duty to ensure their lasting viability. In the coming decades, we will hear more of resource wars, climate change threats, and eminent domain debates, especially in diminishing biodiversity areas, as countries sell or lease off land and other resources to the highest bidder.

\section{Climate Change}

A recent Editorial in the journal Nature cautioned readers that "climate science, like any active field of research, has major gaps in understanding. Yet the political stakes have grown so high in this field, and the public discourse has become so heated, that climate researchers find it hard to talk openly about these gaps"...suggesting that those "who deny humanity's influence on climate will try to use any perceived flaw in the evidence to discredit the entire picture. So how can researchers honestly describe the uncertainty in their work without it being misconstrued?"17

I share similar anxieties, but like most of my colleagues, I believe the evidence clearly shows both natural climate trends, which have shown increasing influence over many decades, along with man's hand in spawning carbon dioxide emissions equally contribute to the predicament we face today. The undisputed accumulation of carbon emissions never will be absorbed or disappear from our environment. This must be curtailed and hopefully the same science that discovered it can also find a way to eliminate it.

The environmental indicators that will remain under heated debate are climate warming, biodiversity, global cycles of nitrogen and phosphorus, freshwater availability, ocean acidification, stratospheric ozone depletion, and land-use change, of which are inter-related. Freshwater availability use is almost at the tipping point. Yemen, as one example, will run out of all water in four years. Ocean acidification impacts anyone who resides on or close to an island nation. The challenges are different with each island, but most serious is general sea level rise, the detrimental effects of increased acidification of sea water on coral reefs, and the eventual collapse of the reef ecosystem. Over several decades, millions of islanders will be forced to relocate. Interestingly, current studies suggest that this migration will be regional migration rather than international, mostly driven by drought, soil degradation, disappearing islands, and loss of food security. It is claimed that Africans will move north to Mediterranean countries. ${ }^{18-20}$ Polynesians, at least in today's world, will be welcome in New Zealand and Australia. Kiribati, a Polynesian paradise that straddles the equator, will be the first island to be totally evacuated. President Tong, in testimony to the UN General Assembly, emphatically declared that "when people migrate they will migrate on merit and with dignity" hoping for what he calls a "global distribution" of the population. The process is already happening with groups numbering a thousand receiving skilled job training as nurses in New Zealand. Once work is obtained, they will facilitate the continual and orderly exit of others. ${ }^{21}$

Climate changes directly impact the public health. The water quality and supply on the Polynesian Islands is a major health issue. Rapid urbanization results from relocating costal families where population growth, density, and the mounting economic challenges stress the fragile public health infrastructure. Public health risks are being posed by contaminated and polluted home rainwater storage, wells, and lagoons showing elevated bacterial contamination. In landlocked areas like China, severe drought, lack of potable water, and 'super dust storms' have resulted in $>150$ million people that authorities openly admit need to be relocated. Mainly from water shortages and over irrigation, 240 out of 291 major springs have dried up. ${ }^{22}$ Africa, where it is now common to see dried up river beds, has lost many of their deeper aquifers. With rising temperatures and diminishing rains, Lake Victoria has dropped six feet in three years. ${ }^{23}$

China's answer is unique in that it has the capacity to build and populate new cities (such as Shenzhen) that are marketed as modern economic free zones. The major motive however, is to provide the public health infrastructure protections that were severely compromised in cities like Shanghai. This novel approach has merits, but it is not a viable option for most of the world's megacities suffering similar PHEs.

\section{Large-Scale Natural Disasters}

It is important to remind readers, almost five years after Hurricane Katrina, that indirect public health mortality and morbidity continue to plague New Orleans. The breach of the levees caused much chaos and exposed large gaps in sacrosanct preparedness plans. Waters rapidly flooded emergency generators in the basements of hospitals ceasing their capacity to function and forced the permanent closing of Charity Hospital that once served the indigent population for over 250 years. Never financed enough to invest in an electronic surveillance system, all the New Orleans' Department of Health warehoused paper turned to pulp. The public health system and much of its infrastructure came to a halt. With presses out of commission, a small staff of the Times Picayune, a New Orleans newspaper icon, remained behind to post electronic stories. ${ }^{24}$ Over the ensuing months, their readers, alarmed at what appeared to be an unexpected increase in published obituaries, contacted the barebones remnants of the Public Health Department which launched a study that confirmed a $47 \%$ increase in mortality one year post-Katrina. The excess deaths, attributable to loss of a number of social and physical protections, almost five years later, slowly are being recovered. ${ }^{25}$ Immediately there were 38\% fewer hospital and 56\% fewer psychiatric beds. Despite post-Katrina increaess in suicides and mental health problems, psychiatric services continued to suffer with the last inpatient psychiatric bed closing in New Orleans in September 2009. Although funding was requested, as of 2010, a non-paper surveillance system for New Orleans was not budgeted. Experts estimate that it will take $20-25$ years to rebuild the city at the current pace. ${ }^{26}$

The Indian Ocean Tsunami has had a similar history. Despite what arguably is, the most robust voluntary donation program ever, almost six years after the Indian Ocean Tsunami, large gaps in shelter, sanitation, potable water, health facilities, and workers have been reported in countries affected by the disaster. ${ }^{27}$

\section{Globalization E Urbanization}

Being a constructive critic of the economically driven definition of globalization that has dominated our thinking 
over the last 15 years, I have concerns over its impact on public health. During the 1950s, studies showed severe health indices, especially among women and children in the developing world. This prompted the world health leadership to gather in Alma-Ata in central Asia with plans to provide by the year 2000 , equity of health worldwide. The Alma-Ata Declaration assumed that health and education were human rights. ${ }^{28}$ Although major progress was made, the initiative eventually stagnated under political pressures and major internal conflicts especially in Africa. ${ }^{29}$ In contrast, globalization, dominated by World Bank initiatives, took hold in promoting outsourcing opportunities, new industries, and the development of megacity resources that promised employment to many of the world's poor. Many cities grew at the rate of one million people every six months. The mantra of the World Bank initiatives, "improve the economy and everything else will follow," included health, not as a right, but a "responsibility" that those benefiting from a strong economy would buy. Many areas under World Bank development, historically depended on public healthcare hospitals and other facilities for care. During financial growth, some were maintained from the coffers of the developing industries; but in reality, an overall net reduction in expenditures for public health, health, education, and development occurred. Among the employed and unemployed, a widening gap occurred between the new "have and have not" populations. Health inequities of the 1950s Alma-Ata era, returned and worsened among the poor. Urban leadership faced with these disparities, admits that "health for many has become a major security issue." 30

Urbanzation per se is not problematic when public health infrastructure precedes population expansion, where outside sources can provide essentials, such as food, and when the urban economy remains an economic advantage to the country. On the other hand, "rapid urbanization" is an unsustainable process. The public health infrastructure cannot keep up and often collapses, and the failing economy drains the nation-state. Mumbai, the most densely populated city worldwide has $>30,000$ people $/ \mathrm{km}^{2}$, and in some areas, this exceeds one million $/ \mathrm{km}^{2}$. And yet, $>1,600$ new families move into Mumbai every day.

Rapid urbanization has produced an 'invisible population' with unknown demographics or knowledge of their access to basic health. With little or no representation by the humanitarian community, no one could guarantee basic social and physical protections. This situation worsened with the financial crisis, one example being China, where authorities admit to $>26$ million newly unemployed. Most of the young adult unemployed males, who sent money home to support their rural families, are unable to return 'home' where the local communities fear they will take the few available jobs away. Authorities admit to increasing criminality and "mass incidents". 31

The rural poor, as they did during the 1850s Industrial Revolution, flock to urban centers. A poverty-ridden family earning $\$ 2 /$ day will gladly welcome $\$ 4 /$ day despite remaining locked in extreme poverty. In the developed world, 4-6\% of the populations are urban squatters, whereas up to $70 \%$ are in the developing world. ${ }^{32,33}$ Currently, 59 million new urban dwellers are added annually worldwide, $89 \%$ in developing countries. ${ }^{34}$ Megacities like Mumbai reveal blatant evidence of the contradictions of globalization, where multiple modern buildings front miles of decrepit shanty towns.

Goldstone in quoting both The Economist and UN data suggests that "...most of the world's expected population growth will increasingly be concentrated in today's poorest, youngest, and most heavily Muslim countries, which have a dangerous lack of quality education, capital, and employment opportunities; and, for the first time in history, most of the world's population will become urbanized, with the largest urban centers being in the world's poorest countries, where policing, sanitation, and health care are often scarce." 35 Projections of the UN forecasts (Figure 2), "might even understate the reality because they reflect the "medium growth" rates." 36

New occupants tend to move to resource poor and disaster prone areas (i.e., earthquake, flooding) of the cities where sanitation is ignored and infectious diseases more prevalent. Currently, urban settings have the highest worldwide $<5$ years of age and IMR. Dense growth, worsening health indices, poverty, and social tensions are a recipe for increasing disruptive tensions.

A megacity usually is defined as a metropolitan area with a population in. excess of 10 million. ${ }^{37}$ Port-au-Prince, Haiti with a severely dense population of three million did not fit this definition, yet, shared the same problems of abject poverty. It is the density of populations, not the total number, which are the major driver influencing disease, poor sanitation, shelter, unsafe water, and food quality and distribution. If geographic density of populations was used, many more urban settings would be among the growing list of those at great risk. Today, there are over one billion people without "basic food for health," meaning that while they obtain some food, it is not of the quantity or quality (lack of essential micronutrients) to ward off disease. International food programs only feed about $10 \%$ of this population.

\section{Epidemics and Pandemics}

There have been $>70$ new or re-emerging diseases during this past decade. For viruses and other microorganisms that depend on human transmission to survive, it is a wonderful time to propagate. Dense populations and uninhibited air travel are fertile soil for transmission from one human host to another. Severe acute respiratory syndrome (SARS) was the name given to the coronavirus, a relative of the common cold, which began in Guangdong Province, China and spread to 37 countries in 10 days. Guangdong Province, one of the most densely populated areas of the world, is highly vulnerable to the emergence and re-emergence of common and rare viral pathogens. But it is not just about viruses. In January 2010, one of the smallest yet dense island nations, the Marshall's, was declared a "public health emergency". This happened following an outbreak of drug-resistant tuberculosis (TB), a large mycobacterium, when government authorities considered calling upon special powers of quarantine for people who were not complying with TB prevention requirements. ${ }^{38}$ Little known is that between 1969 and today, bubonic plague cases which number only 10-15 per year have spread from northern New Mexico to all states west of the Mississippi. ${ }^{39}$ The difference between these cases 


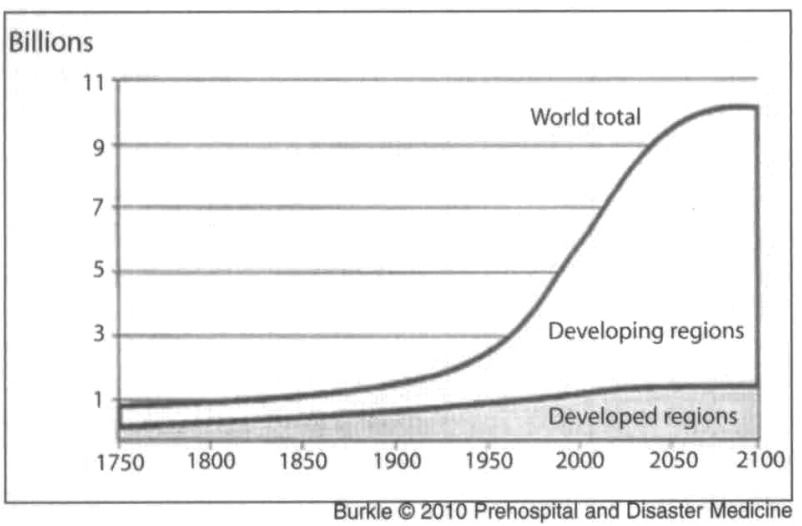

Figure 2-Population growth: 1750-2100. The global population doubled between 1950 and 1987, from 2.5 billion to 5 billion. Reaching the first 2.5 billion took the human species from its beginnings up to 1950; the second 2.5 billion took less than 40 years. Reproduced from: Merrick TW, et al: World Population in Transition. Population Bulletin 1986;41(2):44-45.

and those in Africa and India, for example, is the capacity of public health surveillance and management systems in the United States to deal with these threats on a daily basis.

Both SARS and the recent $\mathrm{H} 1 \mathrm{~N} 1$ can be seen as dry runs for what eventually is predicted to be a pandemic of a more lethal viral pathogen. Viruses mutate incessantly in order to remain viable pathogens. Avian influenza, which to date has not mutated in the one genomic area that would ensure easy human to human spread, has a mortality rate between $40-60 \%$. The poorer the country, the higher the mortality rate. Surveillance systems that are critical to the discovery, investigation, and control of infectious diseases have markedly improved in the developed world out of fear to protect their populations and economies. These systems, though, remain inadequate in developing countries where the emergence and spread of pathogens is most likely.

The SARS experience prompted a modernization of the International Health Regulations (IHR) which legally binds countries to work together to prevent, protect, and control the spread of infectious disease. With SARS, the IHR became a Treaty in 2007 and, to date, has proven to be a successful model for global cooperation to protect the public health. ${ }^{40,41}$ However, even with impressive advances in the science of pandemics and in strategic and tactical preparedness, local community operational level plans and capacity remain deficient. Western models of care are individual and hospital-centric. Epidemics and pandemics are by definition, PHEs that demand a population-based approach requiring unprecedented coordination and cooperation between the clinical workforce and public health authorities. Operational requirements for communities call for robust tele-healthline systems, surge allocation of scarce resources, system-wide integrated triagemanagement, citizen-supported self or self-assisted care, and alternative health facilities, to name but a few.

\section{Emergencies of Scarcity}

Alex Evans, a Fellow at the Center on International Cooperation at New York University, has been at the forefront of alerting society about the need to see energy, food, climate, and water security as "different facets of the same underlying issue of resource scarcity, rather than as separate issues that happen to share a few attributes." The driver of these emergencies is the increasing worldwide demand: energy rise of $45 \%$ and food $50 \%$ by 2030 , and water $25 \%$ by 2025 . He cautions that the pattern of trying to manage one scarcity at a time without taking the others into consideration creates a "major risk of unintended consequences". ${ }^{42}$ Distributional conflicts are already emerging. Resource wars, called complex internal wars, that began among emerging post-Cold War countries in the 1990 s were the first hint of problems to come.

These emergencies are inextricably linked to biodiversity hotspots, climate threats, and the scarcity of remaining forests and arable lands, most of which lie in the least developed countries. Import dependent countries, such as China, Japan, South Korea, and many in the Middle East claim the right to purchase farmland in foreign countries to meet national food security needs at home. For almost two years, South Korea negotiated a no-cost, 100-year lease of half of all arable land in Madagascar; a country suffering severe unemployment and poverty. Local farmers had no political voice in the negotiations. South Korea's plan was to exclusively grow corn for their countries' food staple and claim ownership of the land's massive water reserves. When details of this arrangement reached the populace, a political coup abruptly ended the contract. The South Korean government response, "We want to plant corn there to ensure our food security. Food can be a weapon in this world," reveals much to worry about. ${ }^{43}$ Curiously, the fact that this event did not make even a ripple in the world's press or psyche is equally alarming. Similar purchases of energy from Africa, and the Artic, South China, and Caspian Seas by individual countries now are commonplace.

For many decades, the public health of a country was revealed by disasters that kept governments honest by immediately defining the public health and exposing its vulnerabilities. ${ }^{44}$ Not surprisingly, governments in power were either replaced post-disaster by election or by coup. Hurricane Katrina and the Haiti earthquake proved the capstone events that exposed the state of public health protections, not that they were very well hidden. Scarcity of energy, water, and food already defines the public health in many countries, but in the near future, these capacities will be the indices to measure the public health country by country.

Evans suggests key agendas to build resilience to scarcity among "poor people and fragile states". 42

1. Improve surveillance and early warning and cites the G20 Global Impact and Vulnerability Alert System of April 2009 that integrates data about conflict risk, human vulnerability, and political economy dynamics.

2. Mitigate unsustainable population growth. Any reduction requires the empowerment of women, a status not acceptable in most countries that have dense populations.

3. Focus on and support agriculture, especially small farms with technological know-how and micro-credit programs.

4. Initiate social protection systems and safety nets to reduce vulnerability. 
5. International effort to scale-up capacity of natural resource governance.

6. Connect conflict prevention resolution with natural resource scarcity in mediation and prevention.

7. Upgrade emergency capacity to deal with scarcity crises.

\section{Impact on Policy and Public Health}

The way in which we perceived and defined public health began to change several decades ago. Environmental and public health professionals no longer are defined by a "narrow sanitary engineering approach". 45 Current public health reflects governance, transportation, communication, public safety, the judiciary, and other civil sectors that allow a village, town, city, and nation-state to functionally integrate in providing social and physical protections. This also defines the new public health system and its infrastructure. Many of the younger generation already are chest-deep into globalization as a planned career. New global public health programs at the undergraduate level in 137 universities and colleges have tripled their enrollment in the last three years. ${ }^{46}$ Increasingly, physicians, nurses, lawyers, engineers, and economists, just to name a few, are seeking a combined degree with public health. For the most part, this has been their own decision; correctly derived from awareness that public health greatly impacts every discipline. Global health concentrations in schools of public health at the graduate and undergraduate levels are increasingly being launched and refined. Suffering from a post-Sputnik era that favored more vertical concentrations in the sciences to win the Cold War, there is realization now that global health studies require a highly integrative approach that is multidisciplinary, multi-sectoral, and supports the multi-ministerial levels of decisions that are necessary. ${ }^{47}$ Science and the humanities must again be equal partners in education.

Whereas politically sensitive issues have been restricted from US public education for decades, there must be a reevaluation of this shortsighted decision, with global health taking center stage from elementary school on. Other countries are not so impeded. Academia, starting at the grade school level must be the honest broker for accountability and transparency between what is being viewed on television and the younger generation's quest for knowledge.

Humanitarian assistance began to move from rural to urban areas two decades ago, as rural wars forced women and their children to flee to escape rape, murder, and the total absence of social protections. Many of us spent the early decades training the nascent humanitarian community in building rural refugee camps, wells, pit latrines, defecation fields, and learning basic field epidemiology. Now, many of these same women find themselves trapped in urban settings with few social protections and scant opportunities for work except prostitution. The state of health for women and children is worse now than when I began my humanitarian career $>45$ years ago. Those who define themselves as humanitarian professionals have doubled from a decade ago to almost 200,000 today. They are eager and well traveled. But like us all, they do not know what they don't know. Much of the education and training remains outdated. The humanitarian community, policy wonks, and the military have entered the $21^{\text {st }}$ century unprepared to protect the urban public health or handle emergencies of scarcity.

When it comes to emergencies of scarcity, no developing or developed country alike should be excluded in meeting Evans' key agendas. Land grabbing and the failure of a concerted "cry of foul" by the rest of the world defines the power and influence that rich countries believe they are entitled to. If it was not for media attention, the Madagascar case would not be known. Land grabbing will continue to severely impact poor people and fragile states which lack the social protections and political and institutional means to resolve access to resources. What is most troublesome is that power brokers do not see this as a major problem, but as a right of countries with means to protect themselves. The answer to our future crises must be a global solution, not one dictated by any one individual nation-state.

We know that the world has the food to feed the existing population, yet $>1$ billion starve. Can the global community make what works for the IHR treaty and infectious disease control, for water, food, energy, and climate threats? The global community currently has only two very restrictive choices in managing climate threats. One, 'mitigation' defines the legal and diplomatic efforts of the G20 negotiations that call for reduction in population growth rates, ensuring broad social protections and decreasing carbon emissions. So far, they have failed. The second choice is for populations, impacted directly by these threats, to identify their own vulnerabilities, reduce them through their own means, and learn how to "adapt," defined as the "new resilience." In Polynesia, if adaptation does not work, then governments must have strong migration policies in place to emigrate their populations. ${ }^{21}$

The question that will be hotly debated at every level over the next decade is "what responsibilities apply in human relationships on a global or transnational level." Will "global justice" mature enough to demand of the global community, remediation of past injustices, the establishment of fair terms of cooperation between nations, and willingness to address the basic facts of poverty? ${ }^{48}$ As in Haiti today, will the "collective charity" still be based on "feeling sorry," or strive to understand and reverse the political and economic institutional causes.

The global economy will be judged by the capacity of public health infrastructure and systems, both within individual nation-states, and the willingness of the global community to be a partner in ownership. Shared ownership would set priorities, fund strategic recovery and rehabilitation, and support micro-and macro- financing that gives priority to public health protections, both physical and social. If given the political responsibility, the younger generation will in the next two decades, redefine 'globalization' not from economics alone, but from a foundation of health, education, and human rights. Arguably, this will only be realized if water, energy, food, health, sanitation, and shelter are universally protected. In 2002, world governments agreed to significantly slow the rate of biodiversity loss by 2010. This initiative has failed. In part, this is due to the fact that policy-makers at the international level do not have "any single consolidated and robust source of science on biodiversity and ecosystem services to turn to". ${ }^{49} \mathrm{~A}$ pro- 
posed Intergovernmental Platform on Biodiversity and Ecosystem Services (IPBES) is designed not only to improve links between science and policy, but to invest highly in training-opening unprecedented opportunities for burgeoning scientists worldwide. ${ }^{49}$

What to propose for rapid urbanization is equally troublesome, but Paul Romer, the growth economist, does see a silver lining in China's special economic zones. He suggests that hundreds of these "greener" and better planned "high density charter cities" might provide millions of "desperately poor people their first formal sector jobs" lifting themselves out of poverty faster. ${ }^{50}$ Whatever the solutions, they will be multidisciplinary with a public health core.

There is nothing in this prediction that should limit sovereignty or threaten cultures or religions. The "grand experiment," which the IHR Treaty represents, must be analyzed to see if its principles can do for future crises what it already has accomplished in controlling infectious disease outbreaks. ${ }^{51}$ Whereas, the WHO is the rightful home for threatening diseases, a heavily resourced Office for the Coordination of Humanitarian Affairs (OCHA) under a similar Treaty, could become equally responsible for emergencies such as large-scale natural disasters, and emergen-

\section{References}

1. Altevogt BM, Pope AM, Hill MN, Shine KI (Eds.). Research Priorities in Emergency Preparedness and Response for Public Health Systems: A Letter Report. Washington, DC: Institute of Medicine, Board on Health Sciences Policy, 2008, p 13.

2. Burkle FM Jr. Complex Public Health Emergencies. In Koenig KL, Schultz $\mathrm{CH}$ (eds): Disaster Medicine: Comprebensive Principles and Practices. Cambridge University Press, New York, NY. 2010:361-376.

3. Centers for Disease Control and Prevention (CDC): Assessment of epidemiology capacity in State Health Departments: United States, 2009. MMWR 2009;58(49):1373-1377

4. ReliefWeb. Hait: Deforestation and disasters: Humanitarian snapshot 2008. Aug 10 , 2009. Available at http://ocha-gwapps1.unog.ch/rw/rwb.nsf/db900SID/AHAA7USL.XD:OpenDocument\&emid= TC-2008-000143-DOM. Accessed 20 January 2010.

5. ReforestHaiti: International Conference on Reforestation and Environmental Regeneration of Haiti. Honduras, 14-17 Feburary 2007.

6. Burkle FM Jr: Measuring humanitarian assistance in conflicts. Lancet 2008;371(9608):189-190.

7. Degomme O, Guha-Sapir D: Patterns of mortality rates in Darfur conflict. Lancet 2010;375(9711):294-300.

8. Roberts L, Despines M: Mortality in the Democratic Republic of the Congo. Lancet 1999;353(9171):2249-2250.

9. Ghobarah HA, Huth P, Russett B: Civil wars kill and maim people-Long after the shooting stops. American Political Science Review 2003;97(2):189-202

10. Garfield RM, Polonsky J, Burkle FM Jr: Populations exposed to war since World War II. Submitted for publication, January 2010.

11. United Nations Development Group: Report of the UNDG/ECHA Working Group on Transition Issues, Feb, 2004. Available at http://www.google.com/search? client=firefox-a\&rls=org. mozilla\%3AenUS\%3Aofficial\& channel=s\&hl=en\& $q=$ report + of + the + und $\% 2$ Fecha + working+group+on+transiton+issues $\& b$ tnG $=$ Google + Search. Accessed 24 May 2009.

12. Biodiversity Hotspot Project: Biodiversity hotspots. Available at http://www.uwsp.edu/cnr/wcec/envsci/Framework/pdf/LivingResources/Bi odiversityHotspots.doc. Accessed 30 January 2010.

13. Mirtermeier $\mathrm{C}$, Hanson T, Machlis G: Warfare in biodiversity hotspots. Conservation Biology 2009;10(1111):1523-1739.

14. Chulov $M$ : Iraq littered with high levels of nuclear and dioxin contamination, study finds. Available at http://www.guardian.co.uk/world $/ 2010 / \mathrm{jan} / 22 / \mathrm{iraq}$ nuclear-contaminated-sites. Accessed 27 January 2010.

15. Vital Signs 2003. Part Two: Environment Features. VS03, part 2:81-149. Available at http://www.worldwatch.org/system/files/EVS302.pdf. Accessed 28 January 2010. cies of scarcity. The OCHA would be expected to have a strong public health presence, authority, and capacity to monitor, prevent, prepare, and manage. Yet, both the IHR treaty and any movement in the same direction through OCHA are "top-down" approaches. What the world fails miserably at is the definitive "bottom-up" remediation of the causes of poverty, public health protections, and war. The latter requires a rewritten and reformed UN Charter and a Security Council that "operationalizes" the Responsibility to Protect (R2P) $)^{52}$ initiative which is the best hope forward for legitimating "preventive force". ${ }^{53}$ The Western world should support a standing task force for the UN, an idea first proposed and tabled as Article 43 in the 1945 UN Charter.

Lastly, public health must take precedence over politics and not be driven by political motives. We talk of a populist movement in the US. Important, yes, but only when the same issues, such as the "empowerment of women", become a "populist global issue" will measurable results occur. Public health must be seen as a "strategic and security" issue that deserves an international monitoring system, something that the G20's Global Impact and Vulnerability Act must strive to do.

16. The Bushmeat Trade. Available at http:/www.gorilla-haven.org/ghbushmeat.htm. Accessed 27 January 2010.

17. Schiermeier Q: The real holes in climate science. Nature 2010;463:284-287.

18. Baldwin-Edwards M: Migration in the Middle East and Mediterranean: A regional study prepared for the Global Commission on International Migration. January 2005. Available at http://www.childtrafficking.com/Docs/baldwin_05_mig_mid_med_0408.pdf. Accessed 30 January 2010.

19. de Haas $\mathrm{H}$ : North African migration systems: Evolution, transformations and development linkages. International Migration Institute, University of Oxford. Working Paper 6, 2007.

20. IntelliBriefs. North Africa a transit region for international migration. Available at http://intellibriefs.blogspot.com/2010/01/north-africa-transitregion-for.html. Accessed 29 January 2010.

21. Risse M: The right to relocation: Disappearing island nations and common ownership of the Earth. Ethics Es International Affairs 2009;23(3):281-299.

22. Watt J: China at the crossroads. Available at http://www.guardian.co.uk/world/ 2009/may/18/china-ecorefugees-farming. Accessed 05 January 2010.

23. Hanley CJ: Water levels in Lake Victoria dropping fast. Available at http://water-is-life.blogspot.com/2006/12/water-levels-in-lake-victoriadropping.html. Accessed 05 January 2010.

24. Folkenflik D: Katrina marked turning point for 'Time Picayune.' Available at http://www.npr.org/templates/story/story.php?storyld=13984564. Accessed 12 January 2010.

25. Stephens KU Sr, Grew D, Chin K, Kadetz P, Greenough PG, Burkle FM Jr, Robinson SL, Franklin ER; Excess mortality in the aftermath of Hurricane Katrina: A preliminary report. Disaster Med Public Health Prep 2007;1(1):15-20.

26. Quigley B, Finger D: Katrina Pain Index: 2009. The Louisiana Weekly, News Report. Available at http:/news.newamericamedia.org/news/view_article.html? article_id=8a04df63b3b926c80645c8cb2303ala2. Accessed 10 January 2010.

27. Chang MH: Health and housing after the Indian Ocean tsunami. Lancet 2007;369(9579):2066-2068.

28. Rohde J, Cousens S, Chopra M, et at: Declaration of Alma Ata: International conference on primary health care. Alma-Ata, USSR, 6112 September 1978. Available at http://www.who.int/hpr/NPH/docs/declaration_almaata.pdf. Accessed 30 December 2009.

29. Schneider K, Garrett L:The end of the era of generosity? Global health amid economic crisis. Pbilosophy, Etbics, and Humanities in Medicine 2009;4:1-7.

30. Owen JW, Roberts $O$. Globalization, health and foreign policy: Emerging linkages and interests. Globalization and Health 200;1:12-17.

31. Branigan T. Downturn in China leaves 26 million out of work. Available at http://www.guardian.co.uk/business/2009/feb/02/china-unemploymentunrest. Accessed 30 December 2009. 
32. Onyango E: Unplanned settlements, a growing phenomenon in most towns and cities. Knowledge Matters: Tanzania. Posted 23 January 2010.

33. Tanzania Information Brief: Cities without slums: Sub-regional programme for eastern and southern Africa. Available at http://ww2.unhabitat.org/campaigns/tenure/documents/Tanzania.doc. Accessed 14 January 2010.

34. Brennan EM: Population, urbanization, environment, and security: A summary of the issues. Environmental Change Es Security Project Report, Woodrow Wilson Center for International Scholars, Washington, DC. Issue 5, No.22, Summer 1999:4-14.

35. Goldstone JA: The new population bomb: The four megatrends that will change the world. Foreign Affairs 2010;89(1):31-43.

36. Merrick TW: World population in transition. Population Bulletin $1986 ; 41(2): 44-45$.

37. How big can cities get? New Scientist Magazine 17 June 2006:41.

38. Pro-MED-mail Post: Tuberculosis, drug resistance: Marshall Islands. Available at: http://topnews.us/content/210458-tb-health-emergency-marshall-islands. Accessed 31 January 2010.

39. US Centers for Disease Control and Prevention: Questions and answers about plague. Available at http://www.cdc.gov/ncidod/dvbid/plague/qa.htm. Accessed 03 December 2009

40. Burkle FM Jr: Pandemics: State Fragility's Most Telling Gap. In Cronin P. (Ed.), Global Strategic Assessment 2009: America's Security Role in a Changing World. Washington, DC: Institute for National Strategic Studies, National Defense University, US Government Printing Office, 2009, pp 105-108.

41. Baker MG, Fidler DP: Global public health surveillance under new international health regulations. Emerg Inf Dis 2006;12(7):1058-1065.
42. Evans A: Managing scarcity: The institutional dimensions. Available at http://www.globalpolicy.org/security-council/dark-side-of-naturalresources/other-articles-analysis-and-general-debate/48191.html. Accessed 21 September 2009.

43. Jung-a $S$, Oliver $C$, Burgis $T$ : Daewoo to pay nothing for vast land acquisition. Available at http://www.ft.com/ $/ \mathrm{cms} / \mathrm{s} / 0 / \mathrm{b0099666-b6a4-11dd-89dd-}$ $0000779 \mathrm{fd} 18 \mathrm{c}$.html?nclick_check=1. Accessed 12 November 2010 .

44. Burkle FM Jr, Rupp G: Hurricane Katrina: Disasters keep us honest.(Commentary). Monday Developments 2005;23(17):5.

45. Burkle FM, Jr.: Globalization and disasters: lssues of public health, state capacity and political action. Journal of International Affairs 2006:241-265.

46. Howland K, Kirkwood BA, Ward C, et al. Liberal education and public health: Surveying the landscape. Peer Review 2009;11(3):5-8.

47. MacLachlan M: Rethinking global health research: Towards integrative expertise. Globalization and Health 2009;5:6.

48. Miller D: National Responsibility and Global Justice. New York: Oxford University Press, 2007, p 264.

49. Hoag H: Confronting the biodiversity crisis. Nature Reports May 2010;4:51-54.

50. Gunn D: Can Charter Cities change the world? A Q \& A with paul Romer The New York Times 05 May 2010

51. Burkle FM Jr; The grand experiment: International health regulations, pandemics, and future emergencies of scarcity. Presented at the US-CHINA Symposium on Comparative Governance, 14-16 October 2009 co-sponsored by the Kissinger Institute on China and the United States, Woodrow Wilson International Center for Scholars, Washington DC, and the Counselor's Office, State Council, People's Republic of China. pp 1-7.

52. Evans G, Sahnoun M: The responsibility to protect. Foreign Affairs 2002:81(6).

53. Sofaer AD: The best defense? Preventive Force and International Security Foreign Affairs 2010;89(1):109-118. 
DID YOU KNOW:.

Prehospital and Disaster Medicine has published more manuscripts about mass gatherings than any other joumal?

A compendium of all of these papers, with introductory comments by Paul Arbon will be available soon.

If you would like more information about this compendium, please contact the PDM Editorial Office at pdm@medicine.wisc.edu.

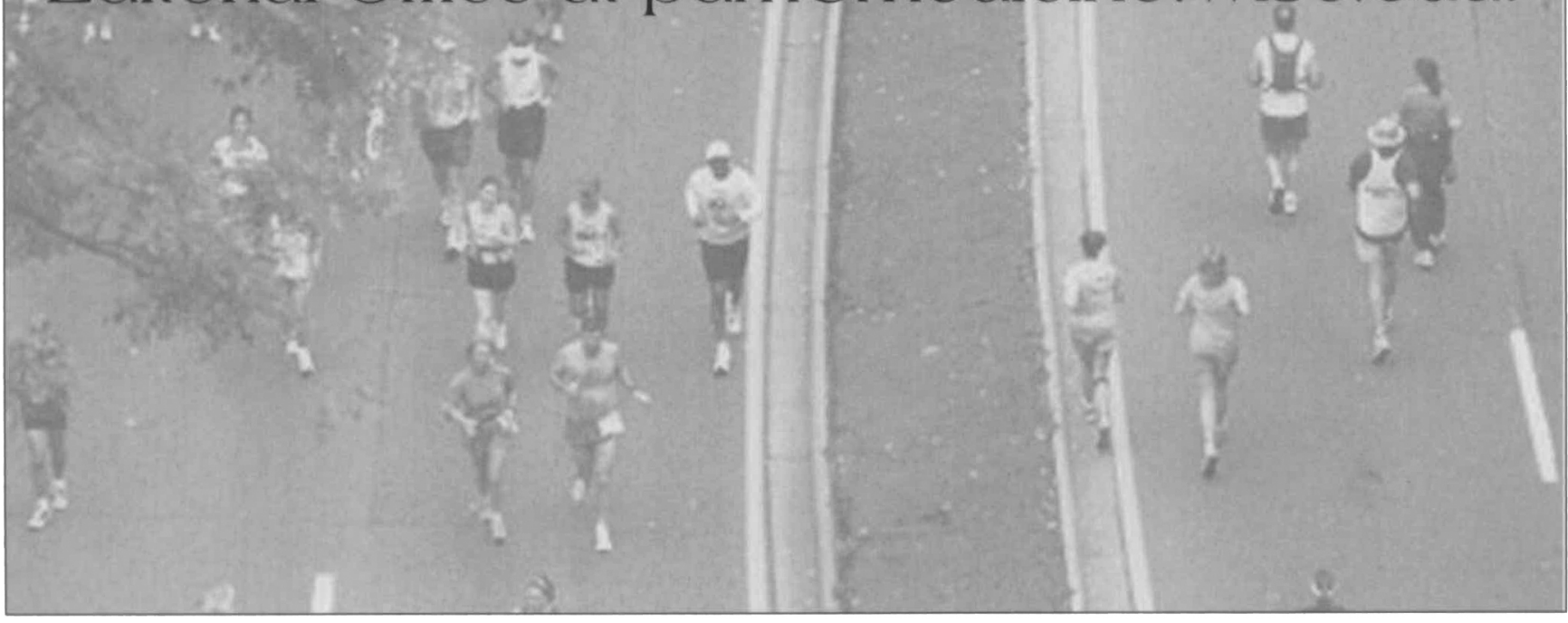

